\title{
Pedagogical Lexicography: Towards a New and Strict Typology Corresponding to the Present State-of-the-Art
}

Sven Tarp, Department of Afrikaans and Dutch, University of Stellenbosch, South Africa, and Centre for Lexicography, Aarhus School of Business and Social Sciences, University of Aarhus, Denmark (st@asb.dk)

\begin{abstract}
A frequent and well-known problem within lexicography is the use of various terms to denominate the same phenomenon as well as the use of the same term to denominate various, completely different phenomena. Such a non-systematic terminology may lead to confusion in the discipline and hamper its theoretical and practical development. The problem is especially severe within so-called pedagogical lexicography. A short panoramic review shows that especially the terms "pedagogical lexicography/dictionaries", "didactic lexicography/dictionaries", "school dictionaries" and "learners' dictionaries" are used with a lot of different meanings that vary from author to author, from country to country, from culture to culture. Although publishing houses could hardly be expected to use a strict terminology for their products, this should nevertheless be expected from theoretical lexicography. In order to overcome the present confusion, it is therefore urgent to establish a typology that can be used as reference by scholars dealing theoretically with the subfield of pedagogical lexicography. The article will first show the amazing variety of meanings addressed to the various terms in the theoretical literature. It will then approach the problem along two different lines: 1) establishing a clear definition of the terms "pedagogical", "didactic", "school" and "learner" in a lexicographical perspective, and 2) referring to the existing practice where the terms are frequently used in a much broader sense than in the theoretical literature. Based upon these considerations, a new and strict typology that corresponds to the present practice of pedagogical lexicography will be presented.
\end{abstract}

Keywords: PEDAGOGICAL LEXICOGRAPHY, PEDAGOGICAL DICTIONARIES, LEARNERS' LEXICOGRAPHY, LEARNERS' DICTIONARIES, SCHOOL DICTIONARIES, CHILDREN'S DICTIONARIES, DESK DICTIONARIES, COLLEGE DICTIONARIES, DICTIONARIES FOR FOREIGN-LANGUAGE LEARNERS, DICTIONARIES FOR MOTHER-TONGUE LEARNERS, DICTIONARIES FOR LEARNERS OF SCIENTIFIC DISCIPLINES

Opsomming: Pedagogiese leksikografie: Op weg na 'n nuwe en streng tipologie wat ooreenstem met die huidige gebruik daarvan. 'n Algemene en bekende probleem binne die leksikografie is die gebruik van verskeie terme om na 'n enkele verskynsel te verwys, sowel as die gebruik van 'n enkele term om na verskeie, heeltemal verskillende verskynsels te verwys. So 'n niesistematiese terminologie kan tot verwarring binne die vakgebied lei en kan die teoretiese en praktiese ontwikkeling daarvan belemmer. Die probleem is besonder ernstig 
binne die sogenaamde pedagogiese leksikografie. 'n Kort, wye oorsig toon dat veral die terme "pedagogiese leksikografie/woordeboeke", "didaktiese leksikografie/woordeboeke", "skoolwoordeboeke" en "aanleerderswoordeboeke" gebruik word in baie verskillende betekenisse wat van outeur tot outeur, land tot land, en kultuur tot kultuur verskil. Alhoewel daar allermins van uitgewers verwag kan word om 'n streng terminologie ten opsigte van hulle produkte te gebruik, behoort dit tog van die teoretiese leksikografie verwag te kan word. Om die huidige verwarring te oorkom, is dit dus dringend noodsaaklik om 'n tipologie te vestig wat gebruik kan word deur vakkundiges wat teoreties omgaan met die subveld pedagogiese leksikografie. Hierdie artikel sal eerstens die groot verskeidenheid betekenisse aantoon wat aan die verskillende terme toegeskryf word wat in die teoretiese literatuur voorkom. Daarna sal die probleem van twee verskillende kante benader word: 1) die vestiging van 'n duidelike definisie vir die terme "pedagogies", "didakties", "skool-" en "aanleerder-" vanuit 'n leksikografiese perspektief, en 2) die verwysing na die bestaande praktyk waar die terme dikwels in 'n baie breër sin as in die teoretiese literatuur gebruik word. Gebaseer op hierdie oorwegings word 'n nuwe en streng tipologie wat ooreenstem met die huidige gebruik in die pedagogiese leksikografie voorgestel.

Sleutelwoorde: PEDAGOGIESE LEKSIKOGRAFIE, PEDAGOGIESE WOORDEBOEKE, AANLEERDERSLEKSIKOGRAFIE, AANLEERDERSWOORDEBOEKE, SKOOLWOORDEBOEKE, KINDERWOORDEBOEKE, HANDWOORDEBOEKE, WOORDEBOEKE VIR VREEMDETAALAANLEERDERS, WOORDEBOEKE VIR MOEDERTAALLEERDERS, WOORDEBOEKE VIR LEERDERS VAN WETENSKAPLIKE DISSIPLINES

\section{Introduction}

A frequent and well-known problem within lexicography is the use of various terms to denominate one and the same phenomenon as well as the use of one and the same term to denominate various, completely different phenomena. Such a non-systematic terminology may lead to confusion in the discipline and hamper its theoretical and practical development. The problem is especially severe within so-called pedagogical lexicography as shown by Welker (2008) who provides the - so far - most comprehensive panorama of this important subfield of lexicography with references to almost 800 titles. A small anecdote will illustrate the problem. In a book which I published in 2008 and where I, among other things, criticized this inconsequent practice, I defined a learner's dictionary as follows (Tarp 2008: 125):

A learner's dictionary is a dictionary whose genuine purpose is to satisfy the lexicographically relevant information needs that learners may have in a range of situations in connection with the foreign-language learning process.

Of course, one could discuss some minor things in this definition, for instance whether it should be called foreign language, second language, non-native language, additional language, etc. But apart from that, it cannot be denied that the above definition corresponds to what is generally understood by learner's dictionary among English-speaking lexicographers. It was therefore rather sur- 
prising to read an article by Giacomini and Rovere (2009) who first quoted a contribution by Cowie (1996) entitled The 'Dizionario Scolastico': a Learner's Dictionary for Native Speakers and then commented (p. 21-22):

The question is whether the chosen title is an example of the inconsequence in the use of the concept 'learner's dictionary' criticized by Tarp (2008: 125), or whether his definition is too narrow.

My first reaction was that Giacomini and Rovere's criticism was completely unjustified, first of all because I had defined the term in such a way that nobody could misunderstand it even if they disagreed, and secondly because the definition corresponded to general practice with Cowie as a possible exception. However, after giving it a lot of thought, I reached the conclusion that Giacomina and Rovere may have pointed at a problem that is worth considering. In lexicography, as in any other academic discipline, it is not only necessary to work with well-defined terms; it is also necessary that the definitions reflect the practical and theoretical state-of-the-art of a discipline in constant development. There should also be a logical linguistic relation between the term used and its conceptual content.

In this respect, the lack of a consistent and systematic terminology within pedagogical lexicography is especially deplorable. A short panoramic review shows that especially the terms "pedagogical lexicography/dictionaries", "didactic lexicography/dictionaries", "school dictionaries" and "learners' dictionaries" are used with a lot of different meanings that vary from author to author, from country to country, from culture to culture. Wiegand, for instance, has edited two books on pedagogical lexicography "involving German" (Wiegand 1998 and 2002), which only deal with dictionaries for foreign-language learners, whereas other authors also include first-language learners in the concept. Welker himself insists that the terms "school dictionary" and "learners' dictionaries" should be reserved for dictionaries designed for first-language and second-language learners, respectively, whereas other authors such as Giacomini and Rovere (2009) include dictionaries for first-language learners in the concept of a learners' dictionary; in some countries like South Africa, school dictionaries - frequently bilingual — are produced both for first- and secondlanguage learners; etc.

Although publishing houses may hardly be expected to use a strict terminology for their products, this should nevertheless be expected from theoretical lexicography. In order to overcome the present confusion, it is therefore urgent to establish a typology that can be used as reference by scholars dealing theoretically with the subfield of pedagogical lexicography.

The following reflections aim at establishing such a typology. They will be based upon a study of existing practice as well as the corresponding theoretical literature, especially Herbert Andreas Welker's book Panorama Geral da Lexicografia Pedagógica (General Survey of Pedagogical Lexicography) which contains a collection of - frequently contradictory and even opposed - opinions and 
ideas expressed by a large number of scholars that permits the reader to get a quick overview of the confusion in terms of terminology within pedagogical lexicography (cf. Tarp 2010). This terminological confusion concerns basic concepts such as:

(1) Pedagogical lexicography/dictionaries

(2) Didactic lexicography/dictionaries

(3) Learner's lexicography/dictionaries

(4) School lexicography/dictionaries

(5) Children's lexicography/dictionaries

(6) College lexicography/dictionaries

In the following, these concepts will be discussed and redefined in the light of existing practice with a view to establishing a new and strict typology that corresponds to the present state-of-the-art of pedagogical lexicography. All quotations from non-English texts have been translated into English by the author.

\section{Pedagogical dictionaries versus didactic dictionaries}

For many researchers these two terms are synonymous, but some, e.g. Wiegand $(1998,2002)$, seem to prefer the term pedagogical dictionaries while others, e.g. Hernández (1998), prefer didactic dictionaries. However, although in the current daily language the terms pedagogical and didactic are frequently mixed up and used as synonyms, in the scientific literature it is nevertheless, as Welker (2008) rightly points out, necessary to use the two terms in a strict and correct way. With reference to existing pedagogical literature, Welker himself (p. 21) defines pedagogy as the "theory and science of teaching and education" whereas didactics is the "totality of methods and techniques used in education". In this sense a pedagogical dictionary is a type of dictionary (used in teaching and education), whereas the adjective didactic refers to the quality of the dictionary in terms of learner-friendliness. Welker (2008: 22) concludes:

... didactics should only be used in order to qualify the way in which the information is provided: more or less didactic, more or less clear, more or less adapted to the users' skills. In this respect, even pedagogical dictionaries may vary in their didactic quality.

So, what is pedagogical lexicography? What is a pedagogical dictionary? First of all, it is important to state that the two terms are hypernyms. But to what? Welker (2008: 18) provides the following definition:

Pedagogical lexicography includes all dictionaries conceived for learners of either a foreign language or the mother tongue. 
This definition seems to be accepted by many scholars and also corresponds to the one given in the Dictionary of Lexicography (Hartmann and James 1998: 107):

\section{pedagogical dictionary}

A reference work specifically designed for the practical didactic needs of teachers and learners of a language. The distinction usually made between a dictionary for native speakers (school dictionary) and one for non-native learners (learner's dictionary) is not helpful.

as well as to the one furnished by the Nordisk Leksikografisk Ordbok (Bergenholtz et al. 1995: 214):

\section{pedagogical dictionary}

A dictionary especially designed for certain user groups as a tool to assist language learning.

However, when one looks at existing lexicographical practice it seems that all three definitions - i.e. the definitions provided by Welker, Hartmann and James, and Bergenholtz et al. - are somewhat problematic. Among the thousands of relevant dictionaries, in South Africa alone one may find, among others, the following "atypical" pedagogical dictionaries:

- Illustrated Dictionary of Natural Sciences and Technology Today (Maskew Miller Longman 2006)

- Multilingual Science Dictionary for South African Schools (Longman 2007)

- Sasol Science \& Technology Resource (New African Education Publishers 1998)

None of the above dictionaries seems to have been conceived mainly as a language-learning tool. For instance, in the presentation provided on the back cover of the first of the three dictionaries, one may read that,

It enhances conceptual understanding of key concepts and will help the learners succeed in Natural Sciences and Technology.

The main objective of this and other similar pedagogical dictionaries is, according to the authors or the publishing house, to assist the learning of natural sciences, technology or whichever scientific or practical discipline, i.e. not specifically the learning of neither a native (first) or a foreign (second and third) language. In this sense, i.e. in correspondence with existing lexicographical practice, the terms pedagogical dictionary and pedagogical lexicography should be redefined as follows:

Definition:

A pedagogical dictionary is a dictionary especially designed to assist learners of languages (whether a native or a foreign language) and of scientific and practical disciplines. 


\begin{abstract}
Definition:
Pedagogical lexicography is the branch of lexicography dealing with the theory and practice of pedagogical dictionaries.
\end{abstract}

\title{
3. School dictionaries versus learner's dictionaries
}

For many researchers (e.g. Lagane 1990), school dictionaries are dictionaries for learners of the mother tongue (first-language learners), whereas learner's dictionaries are produced for learners of a foreign (second, third, etc.) language. For other researchers, the two terms refer to dictionaries designed for both types of learners. As already indicated above, in their Dictionary of Lexicography Hartmann and James (1998: 107) are critical of the traditional distinction between school dictionaries and learner's dictionaries:

The distinction usually made between a dictionary for native speakers (school dictionary) and one for non-native learners (learner's dictionary) is not helpful.

Welker (2008: 19) disagrees specifically with this statement by Hartmann and James and writes:

On the contrary, I think that this distinction is very useful and necessary.

There are several reasons why it is both useful and necessary to distinguish between dictionaries for first-language learners and dictionaries for learners of a second, third, fourth, etc. language. The main reason is that these two types of learners do not have the same lexicographical needs - especially at a beginner's level - and these needs have to do with their proficiency level in their first (native) and second (foreign) language, respectively:

- First-language learners, without mastering their own language completely (they are learners), are supposed to be fluent in this language in terms of basic vocabulary and grammar when they start using dictionaries, whereas second-language learners are just beginning to learn the second language when they first consult dictionaries in this language.

- First-language learners are generally still in the process of alphabetization when they start using dictionaries, whereas second-language learners, as a rule, are already alphabetized (although there are important exceptions, especially in multi-language countries like South Africa).

- First-language learners are developing their conceptual thinking and knowledge of the world together with their language skills, whereas second-language learners have already developed their conceptual thinking and knowledge beyond their second-language skills.

So, how should a learner's dictionary be defined? Should it only be understood as a dictionary for learners of a second language? Should it include dictionaries 
for first-language learners? And should it also include learners of a specific LSP?

The broadest definitions found include all three types of language learners. Welker (2008), for instance, defines a learner's dictionary as a dictionary for foreign-language learners (as did Tarp 2008). Cowie (1991) discusses a "Learner's Dictionary for Native Speakers". In the same vein, Giacomini and Rovere (2009) define a learner's dictionary as a dictionary for learners of either a native or a foreign language, i.e. what Welker (2008) defines as a "pedagogical dictionary". Fuertes-Olivera and Arribas-Baño (2008) and Fuertes-Olivera (2010) include dictionaries for LSP learners, e.g. specialized translation students, in the concept of a learner's dictionary. But are these definitions broad enough?

The answer once more has to come from practical lexicography. Although its title does not indicate it, the famous South African Sasol Science $\mathcal{E}$ Technology Resource (Hartmann-Petersen et al. 2001) is, in fact, a specialized dictionary as can be seen from the following article which is formulated and structured according to traditional lexicographical patterns:

\section{layering}

A method of artificial propagation in which a shoot from a plant stem is pegged down and covered with soil. Adventitious roots grow from nodes on the shoot, and when they are established the young plant can be detached from the parent plant. See also marcotting.

The subtitle, printed on the cover of this dictionary, is A book resource for learners, students and trainees in science and technology. In this respect, it cannot be considered anything else than a dictionary for learners of science and technology. This concept of a learner corresponds to the one generally used within education where the term learner is not only used to refer to language learners, but also to learners of any scientific or practical discipline. In this sense, and being consequent with the general use of the term, a learner's dictionary may also be conceived for learners of, say, accounting, law, or even mechanics.

However, it is important to distinguish between learners in the broad sense of the word (life-long learning) and those who are following a study or teaching program. If the term learner's dictionary were to include dictionaries also for life-long learners then it would inevitably include almost all dictionaries as it could be claimed that anybody who consults a dictionary does so in order to "learn" something. The term learner's dictionary should therefore be reserved for dictionaries conceived for learners in the narrow sense of the word, i.e. those following a study, teaching or education program. In this respect, a learner's dictionary is synonymous to a pedagogical dictionary, with the only difference that it is looked at from the point of view of the learner and not from the point of view of the "educator", and it could be redefined as follows:

Definition:

A learner's dictionary is a dictionary especially designed to assist learners of languages (whether a native or a foreign language) and of scientific and practical 
disciplines. A learner's dictionary is synonymous to a pedagogical dictionary but focuses on the learner and not the educator.

This definition of a learner's dictionary, however, leaves the discussion of school dictionaries and their definition unsolved. As mentioned above, there are various approaches and definitions among scholars and this terminological confusion is also reflected in the three dictionaries of lexicography consulted for this article. For example, in his Diccionario de lexicografía práctica, Martínez de Sousa (1995: 143) provides the following double definition under the lemma diccionario escolar (school dictionary):

school dictionary. 1. A language dictionary especially conceived to be used by school children in first-grade education. 2. A language dictionary defining terms used in certain text books in school.

The second part of this definition is interesting because Martínez de Sousa seems to include what is normally called glossaries in his definition. Although almost never discussed in the theoretical literature, these glossaries are highly useful and oft-used lexicographical works and it is, hence, important to consider them as part of the concept of school dictionaries as it has also been emphasized by Gouws and Tarp (2010). The second part of the above definition, however, raises the question why it is only dictionaries conceived for firstgrade education that should be considered school dictionaries. Surprisingly, this definition almost totally contradicts the one found in Nordisk Leksikografisk Ordbok (Bergenholtz et al. 1995: 214) where there is a reference from the lemma skoleordbok (school dictionary), which contains no definition, to the lemma pedagogisk ordbok (pedagogical dictionary) under which the authors, among other things, write that school dictionaries are conceived for:

pupils in the secondary school and part of the upper secondary school.

Finally, the third of the three consulted dictionaries, the Dictionary of Lexicography (Hartmann and James 1998: 122), provides a definition that does not distinguish between various grades of school children:

school dictionary

A dictionary written for school-children, common features of which are a controlled defining vocabulary, a clear design and the incorporation of illustrations. The boundaries between the school dictionary on the one hand, and children's dictionaries, college dictionaries and desk dictionaries on the other, are not clearly demarcated.

Although this definition to a certain degree seems to mix the purpose of a school dictionary and its features, the most important statement seems to be that a school dictionary is "a dictionary written for school-children". In this respect, it is necessary to distinguish between two fundamental types of school dictionaries: 
(1) A school dictionary that is an abbreviated or reduced version of a general-language dictionary.

(2) A school dictionary that is designed from the outset as a lexicographical tool specifically conceived for school children.

A genuine school dictionary is a dictionary of the second type, i.e. a dictionary designed to be used by school children and adapted to their mental, linguistic, cultural, and encyclopedic development. In fact, the Spanish lexicographer Hernández (1989: 52) seems to exclude most of the first type of dictionaries, which he calls "deplorable", from the world of school dictionaries:

When a dictionary is the result of a purely quantitative reduction, it can in no way be considered a work conceived for the user.

As to the distinction between dictionaries for school children of various grades and the different (and opposing) definitions provided by Martínez de Sousa (1995) and Bergenholtz et al. 1995), respectively, this apparent contradiction may be explained by different national traditions. In a global perspective it therefore seems that the definition furnished by Hartmann and James (1998), i.e. a dictionary written for school-children without taking into account their respective grades, is not only the one that corresponds to lexicographical practice in general, but also the only one with a logic linguistic relation between the term and its conceptual content.

However, it is one thing to determine the target user group of school dictionaries in general, it is another to determine their respective content. As mentioned above, in the theoretical literature several different definitions are to be found in terms of this content. The broadest of these definitions - i.e. the one including all types of dictionaries designed to be used in school whatever the specific content and discipline - corresponds to the lexicographic practice in South Africa which can be seen from the following dictionaries published within the last few years:

- Bilingual school dictionary. Afrikaans-Engels/English-Afrikaans (Pharos 2007)

- Learner's Dictionary for Schools. Afrikaans-Engels/English-Afrikaans (Pharos 2010)

- Multilingual Science Dictionary for South African Schools (Longman 2007)

It has already been stated that no scientific theory can be built upon the commercial titles given by the publishing houses in order to stimulate sales. However, it goes without saying that the three dictionaries listed above - and many more could be added to the list - are conceived and published in order to be used by school children in their various learning activities, i.e. the learn- 
ing of languages (whether a native or a foreign language) and scientific disciplines. The concept of a school dictionary should include this common lexicographical practice. In this respect, the term school dictionary may be considered a hyponym to the terms learner's dictionary or pedagogical dictionary and may be redefined in the following way:

Definition:

A school dictionary is a learner's dictionary (or pedagogical dictionary) especially designed to assist school children in learning languages (whether a native or a foreign language) and scientific and practical disciplines.

\section{Children's dictionaries versus school dictionaries}

Just as it was the case with school dictionaries there are also various definitions of children's dictionaries to be found in the theoretical literature. In his Diccionario de lexicografía práctica, Martínez de Sousa (1995: 158) provides the following definition under the lemma diccionario infantil (children's dictionary):

children's dictionary

A dictionary especially conceived to initiate the children in the use of this type of works.

This short definition is somewhat surprising because it only focuses on the didactic aspect in terms of initiation in dictionary use and not on the usefulness of the dictionary itself when consulted by its target user group of children who most probably do not consult it in order to be acquainted with dictionary use but to learn and understand new words, etc. There is no further help in the Nordisk Leksikografisk Ordbok (Bergenholtz et al. 1995: 73-74) which in the relatively long article under the lemma barneordbok (children's dictionary) only lists some features of the type of dictionary without defining it. The Dictionary of Lexicography (Hartmann and James 1998: 20), on the other hand, provides the following article:

\section{children's dictionary}

A dictionary aimed at children. While the transition between the dictionary for younger children and the school dictionary is fluid, the former is less bound by the conventions of the traditional, fully-fledged general dictionary than the latter. It is based on a limited basic vocabulary and uses pictorial illustrations and 'stories' - often humorous - rather than formal definitions, to explain the meaning of the (predominantly concrete) words.

The small definition A dictionary aimed at children is almost self-explanatory and even seems troublesome to the authors as it can be seen in the next sentence where they have problems establishing a dividing line between this type of dictionary and the school dictionary. In fact, almost all scholars discussing children's dictionaries and school dictionaries agree that it is difficult to establish such a dividing line between these two types of dictionaries. For instance, 
Hausmann (1990: 1365), which probably represents the so far most interesting contribution on children's dictionaries, notes that there is no clear dividing line between the two dictionary types and that their titles frequently do not reveal their real content, an opinion also shared by (Bergenholtz et al. 1995: 214) who write:

It can be difficult to establish a boundary between most elementary school dictionaries (beginners' dictionaries) and children's dictionaries.

There seem to be three problems in this apparently difficult discussion. First, it is evident from looking at the features - and not at the purpose or functions - of the two dictionary types that there is a fluid transition from one to the other as stated above by Hartmann and James. Nothing else could be expected. Second, a scientific typology should never be built upon the titles provided by the publishing houses but should be on the purpose and functions of the respective dictionaries. And finally, there seems to be a problem with the logical linguistic relation between the terms used and their conceptual content. In most countries, children start school between the age of 5 and 7 , are considered children at least up to the age of 12 or 14 , and continue school up to the age of 15 or 16 . This means that they, for a long period, are school children. Consequently, if a school dictionary is defined as a dictionary conceived to be used by the pupils in school, most school dictionaries are at the same time "children's dictionaries".

The real distinction to be made is between preschool dictionaries and school dictionaries with both being graded and subdivided into various categories according to the pupils' mental and linguistic development and their growing knowledge about the world. And the same holds true when a distinction has to be made between school dictionaries, on the one hand, and college, desk, and university dictionaries or whatever they are called in the different traditions, on the other hand. The content and features of a dictionary are, of course, extremely important and essential for lexicographical works but if they are used as a basis for a typology this will only lead to terminological confusion because of the evident fluid transition from one type to another. Upon this basis, the term pre-school dictionary as a hyponym to the terms learner's dictionary and pedagogical dictionary, may be defined in the following way:

Definition:

A pre-school dictionary is a learner's dictionary (or pedagogical dictionary) especially designed to assist pre-school children in learning their native (first) language (or, hypothetically, a foreign language and a scientific or practical discipline).

\section{Towards a new and strict typology}

Based upon the above reflections, it is possible to outline a new and strict typology corresponding to the present state-of-the-art of pedagogical dictionaries. This typology, of course, could be approached in different ways. If one focuses on the age of the target user group (its place in the education system), the following typology could be suggested: 


\section{Typology A for pedagogical dictionaries (learner's dictionaries)}
(a) Preschool dictionary
(b) School dictionary
(c) College dictionary

If the focus instead is on the type of learning that the dictionaries are supposed to assist then the following typology could be suggested:

\section{Typology B for pedagogical dictionaries (learner's dictionaries)}

(a) Dictionary for native-language learners

(b) Dictionary for non-native-langue learners

(c) Dictionary for learners of scientific disciplines, etc.

If the two above criteria (age and type of learning) are combined, then the following two typologies could be suggested (the parenthesis indicates that the corresponding type of dictionary will probably not be produced for children at pre-school level):

Typology A for pedagogical dictionaries (learner's dictionaries)

(1) Dictionary for native-language learners
(a) Preschool dictionary
(b) School dictionary
(c) College dictionary

(2) Dictionary for non-native-langue learners
(a) (Preschool dictionary)
(b) School dictionary
(c) College dictionary

(3) Dictionary for learners of scientific disciplines, etc.
(a) (Preschool dictionary)
(b) School dictionary
(c) College dictionary

Typology B for pedagogical dictionaries (learner's dictionaries)

(1) Preschool dictionary
(a) Dictionary for native-language learners
(b) (Dictionary for non-native-langue learners)
(c) (Dictionary for learners of scientific disciplines, etc.) 
(2) School dictionary
(a) Dictionary for native-language learners
(b) Dictionary for non-native-langue learners
(c) Dictionary for learners of scientific disciplines, etc.

(3) College dictionary
(a) Dictionary for native-language learners
(b) Dictionary for non-native-langue learners
(c) Dictionary for learners of scientific disciplines, etc.

\section{Four basic considerations}

The conclusions in this article may seem strange after so many years of terminological uncertainty and confusion. But they are the only logical ones to be drawn if the definitions of concepts should reflect the-state-of-the-art of lexicography and if a logical linguistic relation between the terms used and their content should be established.

The study of the theoretical literature shows an amazing variety of meanings addressed to the various terms used. Furthermore, the study of existing practice indicates that pedagogical, learners' and school dictionaries are produced, not only to assist the learning of a language (whether mother tongue, second language or a specific LSP), but also to assist the learning of science and various disciplines such as technology, mathematics, etc. It is time for this practice to be reflected in the theoretical literature and in a new and strict typology. For the future, it is especially important to take into account the following four basic considerations:

(1) Commercial publishing houses cannot be expected to use scientifically correct terms for their products, especially when some terms have already taken root.

(2) Theoretical lexicography should always work with well-defined terms and concepts.

(3) The definitions should reflect the state-of-the-art of both practical and theoretical lexicography.

(4) There should be a logical linguistic relation between the term used and its conceptual content.

\section{Literature}

Basel, Barbara and Louise Banks (Eds.). 2006. Illustrated Dictionary of Natural Sciences and Technology Today. Cape Town: Maskew Miller Longman. 
Bergenholtz, Henning, Ilse Cantell, Ruth Vatvedt Fjeld, Dag Gundersen, Jón Hilmar Jónsson and Bo Svensén. 1997. Nordisk leksikografisk ordbok. Oslo: Universitetsforlaget.

Bosman, D.B., I.W. van der Merwe and A.S.V. Barnes. 2007. Bilingual School Dictionary. AfrikaansEngels/English-Afrikaans. Cape Town: Pharos.

Cowie, Anthony P. 1996. The 'Dizionario Scolastico': A Learner's Dictionary for Native Speakers. International Journal of Lexicography 9(2): 118-131.

Du Plessis, Madaleine. 2010. Learner's Dictionary for Schools. Afrikaans-Engels/English-Afrikaans. Cape Town: Pharos.

Fuertes-Olivera, Pedro A. and Ascención Arribas-Bano. 2008. Pedagogical Specialised Lexicography. Amsterdam/Philadelphia: John Benjamins.

Fuertes-Olivera, Pedro A. (Ed.). 2010. Specialised Dictionaries for Learners. Berlin/New York: Walter de Gruyter.

Giacomini, Laura and Giovanni Rovere. 2009. Italienische Lernerwörterbücher aus soziolinguistischer Sicht. Lexicographica. International Annual for Lexicography 25: 21-45.

Hartmann, R.R.K. and Gregory James. 1998. Dictionary of Lexicography. London/New York: Routledge.

Hartmann-Petersen, Preben, Gus Gerrans and Rasmus Hartmann-Petersen. 2001. Sasol Science \& Technology Resource. A Book Resource for Learners, Students and Trainees in Science and Technology. Observatory/Claremont: Infosource.

Hausmann, Franz Josef. 1990. Das Kinderwörterbuch. Hausmann, Franz Josef, Oskar Reichmann, Herbert Ernst Wiegand and Ladislav Zgusta (Eds.). Wörterbücher, Dictionaries, Dictionnaires. An International Encyclopedia of Lexicography II: 1365-1368. Berlin/New York: Walter de Gruyter.

Hernández, Humberto. 1989. Los diccionarios de orientación escolar. Contribución al estudio de la lexicografía monolingüe española. Lexicographica Series Maior 28. Tübingen: Max Niemeyer Verlag.

Hernández, Humberto. 1998. La lexicografía didáctica del español: aspectos históricos y críticos. Fuentes Morán, María Teresa and Reinhold Werner (Eds.). 1998. Lexicografías iberorománicas: problemas, propuestos y proyectos: 49-79. Madrid/Frankfurt am Main: Iberoamericana and Vervuert.

Lagane, René. 1990. Les dictionnaires scolaires: enseignement de la langue maternelle. Franz Josef Hausmann, Oskar Reichmann, Herbert Ernst Wiegand and Ladislav Zgusta (Eds.). Wörterbücher, Dictionaries, Dictionnaires. An International Encyclopedia of Lexicography II: 1368-1378. Berlyn/New York: Walter de Gruyter.

Martínez de Sousa, José. 1995. Diccionario de lexicografía práctica. Barcelona: Biblograf.

Sutton, Kathleen (Ed.). 2007. Multilingual Science Dictionary for South African Schools. Cape Town: Longman.

Tarp, Sven. 2008. Lexicography in the Borderland between Knowledge and Non-knowledge. General Lexicographical Theory with Particular Focus on Learner's Lexicography. Tübingen: Max Niemeyer.

Tarp, Sven. 2010. H.A. Welker and Pedagogical Lexicography. Lexikos 20: 730-749.

Tarp, Sven and Rufus Gouws. 2010. Skoolwoordeboeke vir huistaalleerders van Afrikaans. Lexikos 20: 466-494.

Welker, Herbert Andreas. 2008. Panorama Geral da Lexicografia Pedagógica. Brasilia: Thesaurus Editora. 
Wiegand, Herbert Ernst (Ed.). 1998. Perspektiven der pädagogischen Lexikographie des Deutschen. Untersuchungen anhand von Langenscheidts Großwörterbuch Deutsch als Fremdsprache. Tübingen: Max Niemeyer.

Wiegand, Herbert Ernst (Ed.). 2002. Perspektiven der pädagogischen Lexikographie des Deutchen II. Untersuchungen anhand des de Gruyter Wörterbuch Deutsch als Fremdsprache. Tübingen: Max Niemeyer. 